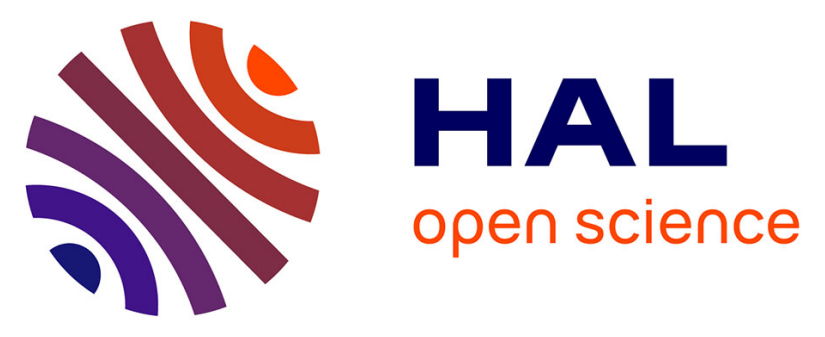

\title{
Nucleic aptamer modified porous reduced graphene oxide/MoS2 based electrodes for viral detection: Application to human papillomavirus (HPV)
}

Fereshteh Chekin, Komal Bagga, Palaniappan Subramanian, Roxana Jijie, Santosh K Singh, Sreekumar Kurungot, Rabah Boukherroub, Sabine Szunerits

\section{To cite this version:}

Fereshteh Chekin, Komal Bagga, Palaniappan Subramanian, Roxana Jijie, Santosh K Singh, et al.. Nucleic aptamer modified porous reduced graphene oxide/MoS2 based electrodes for viral detection: Application to human papillomavirus (HPV). Sensors and Actuators B: Chemical, 2018, 262, pp.9911000. 10.1016/j.snb.2018.02.065 . hal-02189345

\section{HAL Id: hal-02189345 \\ https://hal.science/hal-02189345}

Submitted on 19 Jul 2019

HAL is a multi-disciplinary open access archive for the deposit and dissemination of scientific research documents, whether they are published or not. The documents may come from teaching and research institutions in France or abroad, or from public or private research centers.
L'archive ouverte pluridisciplinaire HAL, est destinée au dépôt et à la diffusion de documents scientifiques de niveau recherche, publiés ou non, émanant des établissements d'enseignement et de recherche français ou étrangers, des laboratoires publics ou privés. 


\title{
Nucleic aptamer modified porous reduced graphene oxide/MoS $\mathrm{S}_{2}$ based electrodes for viral detection: Application to human papillomavirus (HPV)
}

Fereshteh Chekin, ${ }^{\text {a,b }}$ Komal Bagga, ${ }^{c}$ Palaniappan Subramanian, ${ }^{d}$ Roxana Jijie, ${ }^{b}$ Santosh K. Singh, ${ }^{\text {eff }}$ Sreekumar Kurungot, ${ }^{\text {e,f }}$ Rabah Boukherroub, ${ }^{\text {b }}$ Sabine Szunerits, ${ }^{\text {b* }}$

${ }^{a}$ Department of Chemistry, Ayatollah Amoli Branch, Islamic Azad University, Amol, Iran

${ }^{b}$ Univ. Lille, CNRS, Centrale Lille, ISEN, Univ. Valenciennes, UMR 8520-IEMN, F-59000 Lille, France

${ }^{c}$ Advanced Processing Technology Research Center, school of Mechanical and Manufacturing Engineering, Dublin City university, Glasnevin, Dublin 9, Ireland

${ }^{d}$ Department of Chemistry and Nanosciences, Ewha Womans University, Ewhayeodae-gil, Seodaemun-gu, Seoul 120-750, Republic of Korea

${ }^{e}$ Physical and Materials Chemistry Division, CSIR-National Chemical Laboratory, Dr. Homi Bhabha Road, Pune 411008, India

${ }^{f}$ Academy of Scientific and Innovative Research, Anusandhan Bhawan, 2 RafiMarg, New Delhi 110 001, India

\begin{abstract}
Next to graphene nanomaterials, molybdenum disulfide $\left(\mathrm{MoS}_{2}\right)$ offers large surface area that can enhance its biosensing performance. In this work, we investigate the performance of glassy carbon (GC) electrodes modified successively with porous reduced graphene oxide (prGO) and molybdenum sulfide $\left(\mathrm{MoS}_{2}\right)$ for the sensitive and selective detection of the L1major capsid protein of human papilloma virus (HPV). Owing to the difficulties to perform serological assays and HPV cultures efficiently, tools based on molecular recognition are becoming of great importance. We developed here an electrochemical sensor for HPV upon covalent functionalization of the electrode with an aptamer Sc5-c3, a RNA aptamer targeted against the HPV-16 L1 protein. Using differential pulse voltammetry (DPV) and an optimized
\end{abstract}

To whom correspondence should be send to: sabine.szunerits@univ-lille.fr 
sensor interface, a linear relationship between the peak current density of a redox couple such as $\left[\mathrm{Fe}(\mathrm{CN})_{6}\right]^{4-}$ and the concentration of HPV-16 L1 proteins in the range of $0.2-2 \mathrm{ng} \mathrm{mL}^{-1}(3.5$ pM-35.3 pM) could be reached with a detection limit of $0.1 \mathrm{ng} \mathrm{mL}^{-1}$ (1.75 pM). Crossreactivity studies demonstrated high selectivity over potential interfering species such as HPV-16 E6, opening new opportunities of the developed concept for the development of point of care devices.

KEYWORDS: Porous reduced graphene oxide; Molybdenum disulfide; nucleic acid aptamer; human papillomavirus; electrochemical detection 


\section{Introduction}

Papillomaviruses are small (diameter: 52-55 nm), non-enveloped, double stranded DNA viruses that infect mucosal and cutaneous epithealia [1]. They display very high specificity with human papillomaviruses only infecting humans. From the nearly 100 human papilloma virus (HPVs) isolated and described, 35 HPV types are known to infect the human genital mucosa. They are currently categorized with respect to their potential for low, medium or high oncogenic risk [2]. High-risk types such as HPV-16 and HPV-18 are associated with low and high-grade intra epithelial lesions and invasive cancer, while low risk types such as HPV6 and HPV-11 are associated with genital warts and low-grade cervical intraepithelial lesions. Indeed, the finding that HPV is essential for the development of cervical cancer has made HPV a molecular biomarker of HPV-associated cervical cancer [3]. As only $1 \%$ of the infected people present symptomatology, diagnosis is rather complicated and requires, in the asymptomatic cases, specialized equipment to carefully search for internal lesions at the mucous membranes. Molecular diagnosis tools have thus taken over as essential and more patient friendly methods of analysis. At present, nucleic acid hybridization assays, signalamplification assays and nucleic acid amplification are available [4]. The hybrid capture (hc2) signal amplification assay is one of the two FDA approved biochemical methods for the detection of HPV. This signal amplified hybridization assay is based on the hybridization of the target HPV-DNA to RNA probes in solution, followed by capturing using monoclonal antibodies on microtiter plates, followed by amplification with a second monoclonal antibody conjugate labeled with alkaline phosphatase and detection of emitted light by a luminometer [5]. This assay showed excellent analytical capability since it can detect HPV-16 DNA of a concentration down to $1 \mathrm{pg} \mathrm{mL}^{-1}$. The real-time PCR, especially; the Roche Cobas HPV test, which was approved by the US FDA as the first-line primary screen of cervical cancer in 2014, exhibits a detection limit of 600 cells/mL for HPV-16. While considered as highly reliable HPV assays, these methods are time consuming, use expensive instrumentation with the need of an expert to analyze the data. Therefore, these techniques are rather less affordable, limiting their wide implementation into the clinical setting.

The advantages of electrochemical-based hybridization sensors such as low-cost, simplicity of operation and relatively high sensitivity have made this sensing concept an alternative approach for HPV detection [6-19]. One of the first works on this subject is that of the group of O'Sullivan for the detection of HPV-16E6p DNA with a detection limit of 490 pM [10]. Gold electrodes modified with electropolymerized L-cysteine films onto which HPV-16 DNA was linked were described by Campos-Ferreira [9]. Using methylene blue as a redox probe, a 
detection limit for HPV DNA of $18.13 \mathrm{nM}$ with a linear range up to $250 \mathrm{nM}$ were achieved. The HPV type 16 DNA sequence from a partial sequence of the L1 gene was chosen lately as a target. Immobilization of redox-labeled PNA onto chitosan-modified screen-printed carbon electrodes resulted in a sensor able to detect HPV-16 DNA with a 4 nM detection limit and a linear range up to $12 \mu \mathrm{M}$ [7]. One of the currently best performing sensors for HPV is that reported by Wang et al.[8], consisting of gold nanoparticles functionalized with thiolated HPV-16 DNA modified single walled carbon nanotubes. The sensor exhibited a detection limit of $1 \mathrm{aM}$ and a linear range between $1 \mathrm{aM}-1 \mathrm{pM}$ for HPV-16 DNA.

Next to nucleic-hybridization assays, electrochemical sensors are highly adapted for the detection of aptamer-protein interactions [20]. Several aptamers have been proposed against viral proteins to help in the specific detection of the virus, including HPV [21]. One of these structures showing a very low $\mathrm{K}_{\mathrm{D}}$ of $0.05 \mathrm{pM}$ is the RNA aptamer targeting the L1 protein (Sc5-C3) [22]. It consists of a hairpin structure with a 16-nt loop that directly binds the L1 protein.

In this work, we investigate the interest of porous reduced graphene oxide-molybdenum sulfide (prGO-MoS ${ }_{2}$ ) modified GC electrical interfaces as electrochemical transducers for the sensing of HPV-16 L1 proteins. Porous carbon materials have shown to be excellent electrode materials for the development of sensitive bioelectrochemical sensors [23, 24]. They display unique advantages for electrochemical sensors as the resident porosity increases the specific surface area of the electrode, allowing the immobilization of a high amount of ligands, required for enhancing the sensitivity of the sensor. In addition, they promote diffusion of the analyte through interconnected pores, allowing fast sensing. Compared to other porous carbon structures, prGO has shown, next to excellent chemical stability and electrochemical properties, high mechanical strength ensuring the integrity of the porous structures [25, 26]. The interest for non-enzymatic glucose sensing using metallic nanoparticle decorated prGO has been recently reported by $\mathrm{Li}$ et al. [27]. We demonstrated lately the interest of GC electrodes modified with prGO functionalized with anti-gliadin antibodies for highly sensitive detection of gliadin in food samples [24].

The extraordinary properties of layered prGO for sensing have renewed the interest to investigate other 2D materials such as the semiconducting analog of graphene, molybdenum disulfide $\left(\mathrm{MoS}_{2}\right)$ [28-30]. As both $\mathrm{MoS}_{2}$ and rGO have similar morphology and layered structure, the formulation of $\mathrm{MoS}_{2}$-rGO hybrids has shown to maximize their structural compatibility and resulted in improved electrochemical properties [31-35]. We showed indeed 
that a $\mathrm{MoS}_{2}$-rGO modified electrode allowed for the selective analysis of folic acid in the presence of a variety of interference species with a $10 \mathrm{nM}$ detection limit and applicable for the determination of folic acid in human serum [35]. In this work, we investigate the interest

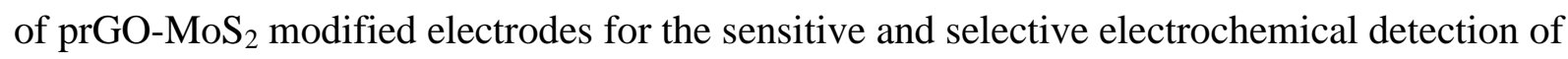
HPV-16. We show, in this article, that such a composite matrix is attractive for modification with aptamers for selective sensing of L1-major capsid protein of HVP-16 with a picoMolar detection limit.

\section{Experimental}

\subsection{Materials}

Molybdenum(IV) sulfide powder $\left(\mathrm{MoS}_{2}\right)$, 11-mercaptoundecanoic acid (MUA), poly(ethylene glycol) methyl ether thiol (average $\mathrm{M}_{\mathrm{W}}=800$, HS-PEG), potassium hexacyanoferrate(II) $\left(\left[\mathrm{K}_{4} \mathrm{Fe}(\mathrm{CN})_{6}\right]\right)$, hydrazine hydrate, hydrogen hydroxide $\left(30 \%, \mathrm{H}_{2} \mathrm{O}_{2}\right)$, human serum albumin (HSA), ovalbumin (OVA), $N$-ethyl- $N^{\prime}-(3-$ dimethylaminopropyl)carbodiimide $\quad$ (EDC), $\quad N$-hydroxysuccinimide $\quad(\mathrm{NHS}), \quad N, N^{\prime}-$ disuccinimidyl carbonate ( $\geq 95.0 \%$, DSC), dichloromethane $\left(\geq 99.8 \%, \mathrm{CH}_{2} \mathrm{Cl}_{2}\right)$, and phosphate buffer tablets (PBS, 0.1 M) were purchased from Sigma-Aldrich and used as received.

The 3'-amine modified HPV-16 L1 aptamer (5'-GGG-AAC-GGG-AAC-AAA-AGC-UGCACA-GGU-UAC-CCC-CGC-UUG-GGU-CUC-CCU-AUA-GUG-AGU-CGU-AUU-ATT-

TTT- $\mathrm{NH}_{2}$ ) was purchased from Sigma-Aldrich.

The HPV recombinant HPV-16 L1 $\left(\mathrm{M}_{\mathrm{W}}=56 \mathrm{kDa}\right)$ and the negative control E6 protein (18 $\mathrm{kDa})$ were obtained from Abcom.

Graphene oxide (GO) powder was purchased from Graphenea, Spain.

Serum and saliva samples were kindly provided by the Centre Hospitalier Universitaire (CHU), Lille.

\subsection{Electrode preparation}

\subsubsection{Preparation of porous reduced graphene oxide (prGO)}

Reduced graphene oxide (rGO) was prepared from GO precursor using hydrazine reduction. Briefly, to $5 \mathrm{~mL}$ GO $(0.5 \mathrm{mg} / \mathrm{mL})$ aqueous suspension was added hydrazine hydrate $(0.50$ $\mathrm{mL}, 32.1 \mathrm{mM}$ ) and heated in an oil bath at $100{ }^{\circ} \mathrm{C}$ for $24 \mathrm{~h}$ over which the reduced GO gradually precipitated out the solution. The product was isolated by filtration over a PVDF membrane with a $0.45 \mathrm{~mm}$ pore size, washed copiously with water $(5 \times 20 \mathrm{~mL})$ and methanol $(5 \times 20 \mathrm{~mL})$ and dried in an oven at $100{ }^{\circ} \mathrm{C}$ overnight. 
The synthesis of prGO was achieved using a previous method reported by us [36]. rGO powder $(100 \mathrm{mg})$ was dispersed in $30 \% \mathrm{H}_{2} \mathrm{O}_{2}(100 \mathrm{~mL})$, ultrasonicated for $30 \mathrm{~min}$ and the mixture was refluxed for $12 \mathrm{~h}$ at $60{ }^{\circ} \mathrm{C}$. The obtained solution was filtered and the recovered prGO powder was dialyzed to remove excess $\mathrm{H}_{2} \mathrm{O}_{2}$ and separate from small sized graphene quantum dots.

\subsubsection{Coating of glassy carbon electrodes with prGO and $\mathrm{MoS}_{2}$ layers}

Glassy carbon (GC) electrodes polished with alumina powder were modified by drop-casting $5 \mu \mathrm{L}$ of a suspension of prGO $\left(1 \mathrm{mg} \mathrm{mL}^{-1}\right.$ in water) and drying for $24 \mathrm{~h}$. Then $5 \mu \mathrm{L}$ of a suspension of $\mathrm{MoS}_{2}\left(1 \mathrm{mg} \mathrm{mL} \mathrm{m}^{-1}\right.$ in water) was drop-casted onto the top and dried for $24 \mathrm{~h}$ in an oven at $60^{\circ} \mathrm{C}$. The formed $\mathrm{GC} / \mathrm{prGO} / \mathrm{MoS}_{2}$ electrodes were immersed in $0.1 \mathrm{M}$ PBS $(\mathrm{pH}$ 7.0) and cycled 30 times between $-1.5 \mathrm{~V}$ and $+1.1 \mathrm{~V}$ at a scan rate of $0.1 \mathrm{~V} \mathrm{~s}^{-1}$ to stabilize the interface.

\subsubsection{Fabrication of $\mathrm{HPV}-16 \mathrm{~L} 1$ aptasensor $\left(\mathrm{GC} / \mathrm{prGO} / \mathrm{MoS}_{2}-\mathrm{L} 1\right)$}

The $\mathrm{GC} / \mathrm{prGO} / \mathrm{MoS}_{2}$ electrode was immersed into a mixture of 11-mercaptoundecanoic acid $(1 \mathrm{mM}) /$ poly(ethylene glycol) methyl ether thiol (HS-PEG, $1 \mathrm{mM})$ with a mass ratio of 10:1 for $12 \mathrm{~h}$ at room temperature. HPV-16 L1 aptamers were immobilized by first activating the carboxyl groups by immersion into a solution of EDC (15 mM)/NHS (15 mM) in PBS (0.1 M, pH 7.4) for $30 \mathrm{~min}$, followed by covalent coupling of the $3^{\prime}-\mathrm{NH}_{2}$-modified aptamer $(5 \mu \mathrm{L}, 5$ $\mu \mathrm{M}$ in PBS) by incubating for $40 \mathrm{~min}$ at room temperature and washing ( 3 times) with PBS.

\subsection{Characterization and Instrumentation}

\section{Scanning electron microscopy (SEM)}

SEM images were obtained using an electron microscope ULTRA 55 (Zeiss, France) equipped with a thermal field emission emitter and three different detectors (EsB detector with filter grid, high efficiency In-lens SE detector and Everhart-Thornley Secondary Electron Detector).

\section{X-ray photoelectron spectroscopy (XPS)}

X-ray photoelectron spectroscopy (XPS) was performed in a PHI 5000 VersaProbe-Scanning ESCA Microprobe (ULVAC-PHI, Japan/ USA) instrument at a base pressure below $5 \times 10^{-9}$ mbar. Core-level spectra were acquired at a pass energy of $23.5 \mathrm{eV}$ with a $0.1 \mathrm{eV}$ energy step. All spectra were acquired with $90^{\circ}$ between X-ray source and analyzer and with the use of low energy electrons and low energy argon ions for charge neutralization. After subtraction of 
the linear background, the core-level spectra were decomposed into their components with mixed Gaussian-Lorentzian (30:70) shape lines using the CasaXPS software. Quantification calculations (atomic percentage, at. \%) were conducted using sensitivity factors supplied by PHI.

\section{Profilometry}

Profilometry measurements were recorded using a Zygo NewView 6000 Optical Profilometer with MetroPro software. It uses non-contact, three-dimensional scanning white light and optical phase-shifting interferometry. The equipment has vertical $z$-scan measurements ranging from $0.1 \mathrm{~nm}$ to $15000 \mu \mathrm{m}$ and lateral resolution from $0.45-11.8 \mu \mathrm{m}$. This profilometer has capabilities of $1 \mathrm{~nm}$ height resolution with step accuracy better than $0.75 \%$. Images were taken with a $10 \times$ lens with $14 \mathrm{~mm}$ field of view.

\section{Raman spectroscopy}

Micro-Raman spectroscopy measurements were performed on a LabRam HR Micro-Raman system (Horiba Jobin Yvon, France) using a 473-nm laser diode as excitation source. Visible light is focused by a $100 \times$ objective. The scattered light is collected by the same objective in backscattering configuration, dispersed by a $1800 \mathrm{~mm}$ focal length monochromator and detected by a CCD camera.

\section{Electrochemical measurements}

Electrochemical measurements were performed with a potentiostat/galvanostat (Metrohm Autolab, The Netherlands). A conventional three-electrode cell system was employed using a silver wire and a platinum mesh as reference and auxiliary electrodes, respectively. Differential pulse voltammograms (DPV) were recorded within the potential range from -0.1 $\mathrm{V}$ to $+1.5 \mathrm{~V}$ under a modulation amplitude of $5 \mathrm{mV}$ with a step potential of $80 \mathrm{mV}$, step height of $15 \mathrm{mV}$ and step time of $250 \mathrm{~ms}$.

\section{Results and discussion}

\subsection{Fabrication of reduced porous graphene oxide/MoS $\mathrm{S}_{2}$ coated GC electrodes}

Layered 2D MoS 2 is known to be compatible with electrochemical systems due to its metallike character and has been used as electrode material for sensing applications [32, 35, 37-42]. We have demonstrated, recently, that intercalating reduced graphene oxide (rGO) nanosheets into $\mathrm{MoS}_{2}$ resulted in a sensitive and selective electrode material for the detection of folic acid in human serum samples [35]. Here we investigated a successive deposition approach using drop-casting of porous reduced graphene oxide (prGO) followed by $\mathrm{MoS}_{2}$. Figure $1 \mathrm{~A}$ depicts the morphology of a glassy carbon (GC) electrode modified by drop-casting prGO, $\mathrm{MoS}_{2}$ and 
$\mathrm{prGO} / \mathrm{MoS}_{2}$ (one layer). While prGO modified GC interfaces display a porous 3D structure, $\mathrm{GC} / \mathrm{MoS}_{2}$ interfaces exhibit densely packed $\mathrm{MoS}_{2}$ flakes of micrometer size. In the case of $\mathrm{GC} / \mathrm{prGO} / \mathrm{MoS}_{2}$, the morphology of the $\mathrm{MoS}_{2}$ flakes is still present, but a more porous structure is observed, which might be the underlying reason for the increased surface area as determined by electrochemistry.

Figure 1B shows the cyclic voltammograms of the different interfaces by tracing current density vs. potential. The real electrochemical surface area was determined by plotting the peak current as a function of the square root of the scan rate [43]. From the slopes of these graphs and using equation 1 :

$$
A=\text { slope } /\left(268.6 \times n^{3 / 2} \times D^{1 / 2} \times c\right)
$$

where $\mathrm{A}$ is the electrochemical active surface area $\left(\mathrm{cm}^{2}\right), \mathrm{n}$ the number of electrons transferred in the redox event $(\mathrm{n}=1)$, D the diffusion coefficient of $\left[\mathrm{Fe}(\mathrm{CN})_{6}\right]^{4-}\left(5.7 \times 10^{-6} \mathrm{~cm}^{2}\right.$ $\left.\mathrm{s}^{-1}\right)$ and $\mathrm{c}$ the concentration of $\left[\mathrm{Fe}(\mathrm{CN})_{6}\right]^{4-}(10 \mathrm{mM})$, active surface areas of $0.071 \mathrm{~cm}^{2}(\mathrm{GC})$, $0.143 \mathrm{~cm}^{2}$ (GC/prGO), $0.126 \mathrm{~cm}^{2}\left(\mathrm{GC} / \mathrm{MoS}_{2}\right)$ and $0.245 \mathrm{~cm}^{2}$ for $\mathrm{GC} / \mathrm{prGO} / \mathrm{MoS}_{2}$ were deduced and used to determine the current density.

Compared to $\mathrm{GC}, \mathrm{GC} / \mathrm{prGO}$ and $\mathrm{GC} / \mathrm{MoS}_{2}$, the best electron transfer using $\left[\mathrm{Fe}(\mathrm{CN})_{6}\right]^{4-}$ as a redox mediator is observed on a $\mathrm{GC} / \mathrm{prGO} / \mathrm{MoS}_{2}$ composite interface formed by the deposition of one layer of $\mathrm{prGO} / \mathrm{MoS}_{2}$. Further coating with additional $\mathrm{prGO} / \mathrm{MoS}_{2}$ layers did not result in an increase of the current density, but rather in partially blocking electron transfer (Figure 1C). A thickness of $43 \pm 5 \mathrm{~nm}$ was determined for one $\mathrm{prGO} / \mathrm{MoS}_{2}$ layer by profilometric measurements, while two and three $\mathrm{prGO} / \mathrm{MoS}_{2}$ layers resulted in a thickness of $85 \pm 6$ and $123 \pm 4 \mathrm{~nm}$, respectively. This prompted us to use only one layer of $\mathrm{prGO} / \mathrm{MoS}_{2}$ for investigating the electrochemical sensing capabilities of the interface.

(A)
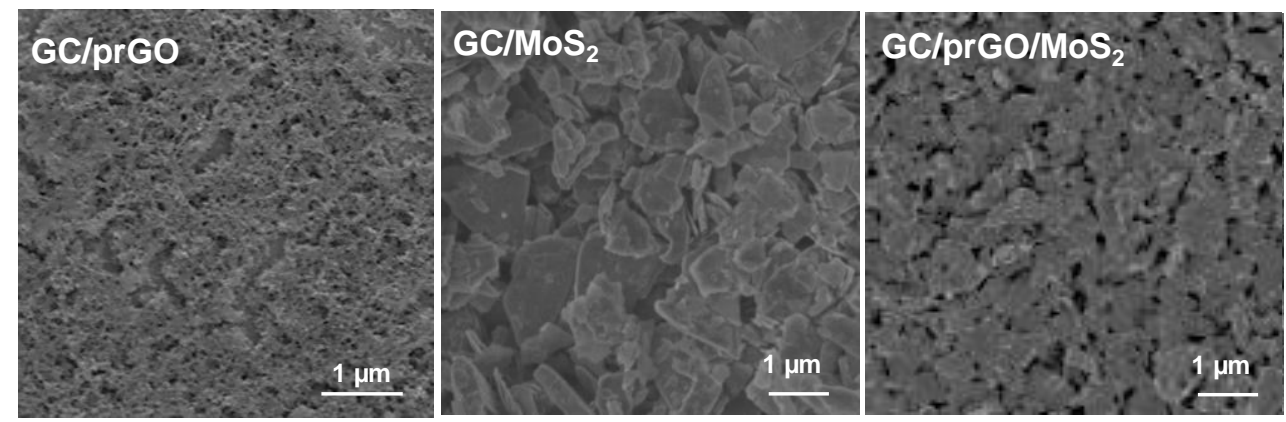
(B)

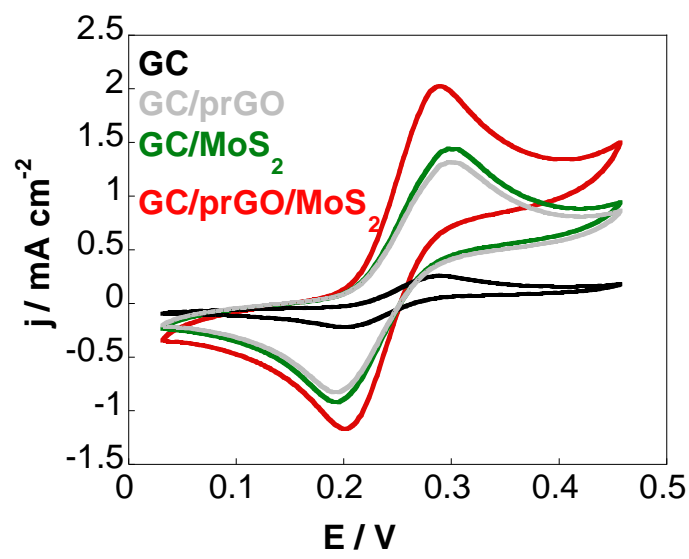

(C)

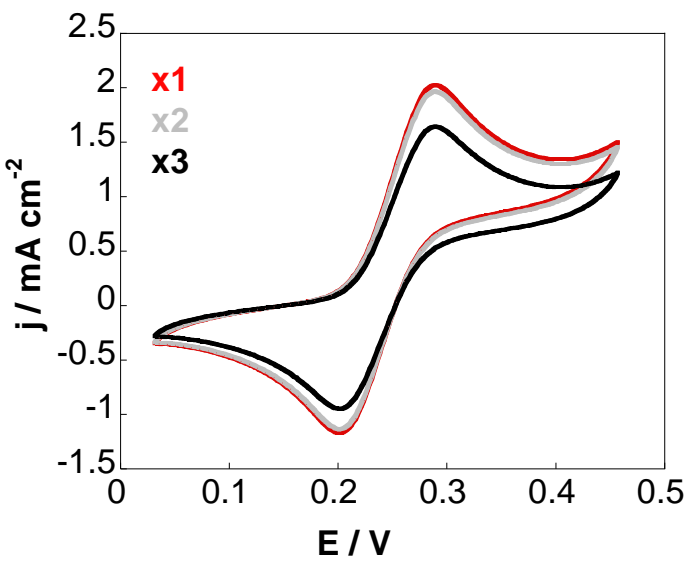

Figure 1: (A) SEM images of $\mathrm{GC} / \mathrm{prGO}, \mathrm{GC} / \mathrm{MoS}_{2}$ and $\mathrm{GC} / \mathrm{prGO} / \mathrm{MoS}_{2}$ (one layer); (B) Cyclic voltammograms recorded on GC (black), GC/prGO (grey), GC/MoS 2 (green) and $\mathrm{GC} / \mathrm{prGO} / \mathrm{MoS}_{2}(\mathrm{red})$ using $\left[\mathrm{Fe}(\mathrm{CN})_{6}\right]^{4-}(10 \mathrm{mM}) / \mathrm{PBS}(0.1 \mathrm{M})$, scan rate $=100 \mathrm{mV} \mathrm{s}^{-1}$; $(\mathrm{C})$ Cyclic voltammograms of GC/prGO/MoS 2 electrodes with 1, 2 and 3 layers of $\mathrm{prGO} / \mathrm{MoS}_{2}$.

\subsection{Integration of HPV-16 specific RNA aptamer}

To harness the good electrochemical signal for sensing, ligand conjugation is required. The inert nature of the $\mathrm{MoS}_{2}$ outer layer makes transition metal chalcogenides challenging to functionalize [44-47]. While the recent report by Chen et al. put into question the modification of $\mathrm{MoS}_{2}$ with organic thiols and proposed physisorption rather than coordination of thiol ligands to $\mathrm{MoS}_{2}$ edges and planes, integration of thiolated poly(ethylene) groups onto $\mathrm{MoS}_{2}$ was reported to lead to stable materials [45]. Chemical functionalization of the $\mathrm{GC} / \mathrm{prGO} / \mathrm{MoS}_{2}$ electrodes was achieved by a simple immersion of the interface into a mixture of thiol-terminated PEG and 11-mercaptoundecanoic acid (MUA) with a mass ratio of 10:1. The $\mathrm{NH}_{2}$-terminated HPV-16 L1 aptamer was then covalently linked to the surface $\mathrm{COOH}$ groups using the classical EDC/NHS chemistry (Figure 2A). The success of the surface modification steps was validated by Raman and XPS spectroscopies.

Figure 2B shows the Raman spectrum of $\mathrm{GC} / \mathrm{prGO} / \mathrm{MoS}_{2}$. The $\mathrm{G}$ and $\mathrm{D}$ characteristic features of carbonaceous structures are clearly seen with the $G$ band centered at around 1585 $\mathrm{cm}^{-1}$ corresponding to in-plane $\mathrm{sp}^{2} \mathrm{C}-\mathrm{C}$ stretching in rings and chains, and the $\mathrm{D}$ band at 1350 $\mathrm{cm}^{-1}$ due to the defects in prGO. The value of $\mathrm{I}_{\mathrm{D}} / \mathrm{I}_{\mathrm{G}}$ is 0.98 , as reported previously $[24,36]$. The position of the $\mathrm{G}$ band might argue for the presence of an important percentage of amorphous carbon, which can be a result of the etching process of rGO [48].

At lower wavenumbers, the characteristic bands due to $\mathrm{MoS}_{2}$ are also visible with bands at $286 \mathrm{~cm}^{-1}\left(\mathrm{E}_{\mathrm{g}}^{1}\right), 383 \mathrm{~cm}^{-1}\left(\mathrm{E}_{2 \mathrm{~g}}^{1}\right), 404 \mathrm{~cm}^{-1}\left(\mathrm{~A}_{1 \mathrm{~g}}\right.$ mode), $450 \mathrm{~cm}^{-1}$ (2LA(M)) mode (Figure 2B). 
The band at $652 \mathrm{~cm}^{-1}$ is believed to be the $\mathrm{A}_{1 \mathrm{~g}}(\mathrm{M})+\mathrm{LA}(\mathrm{M})$ [44]. Modification with thiolterminated PEG and 11-mercaptoundecanoic acid (MUA) results in an increase of the Raman mode at $450 \mathrm{~cm}^{-1}$, reported to be an indictor to probe the disorder and defects in $\mathrm{MoS}_{2}[44$, 49].

(A)
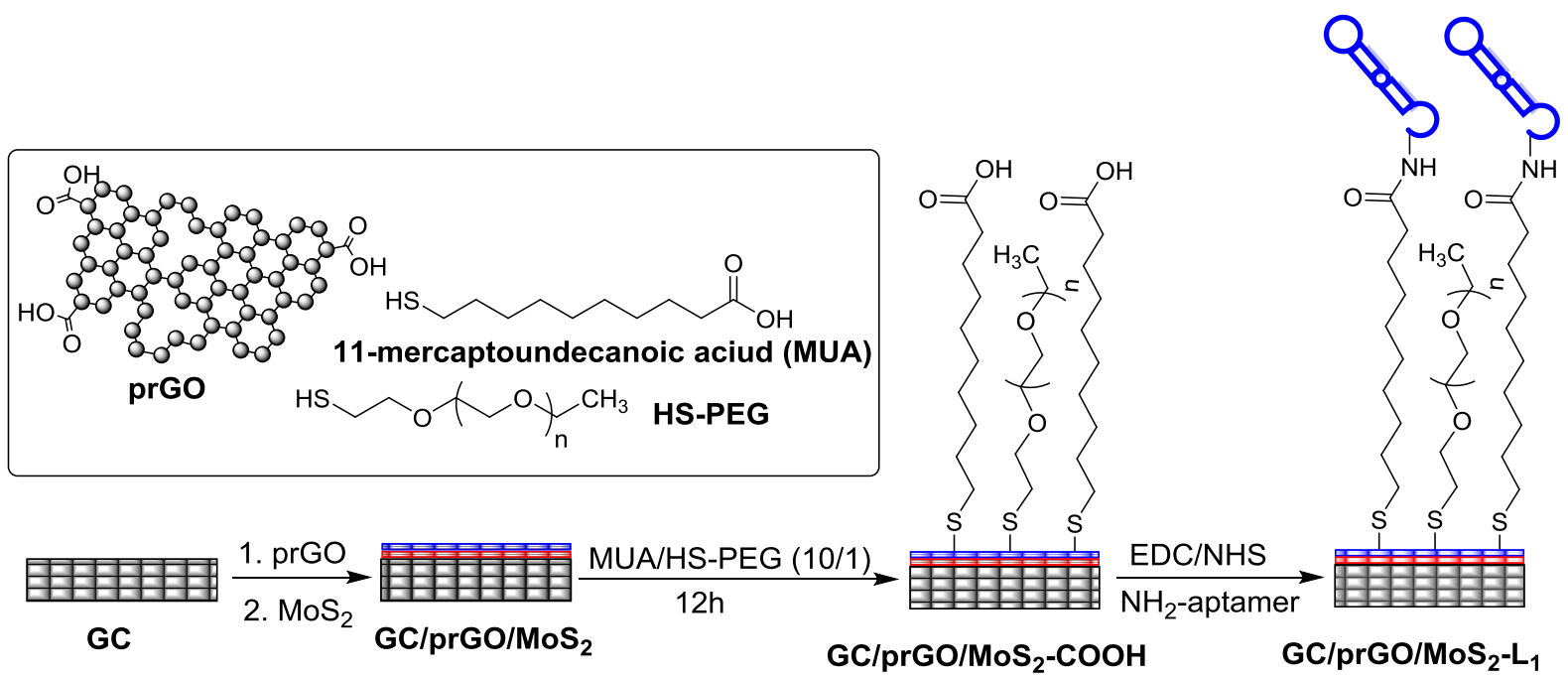

(B)

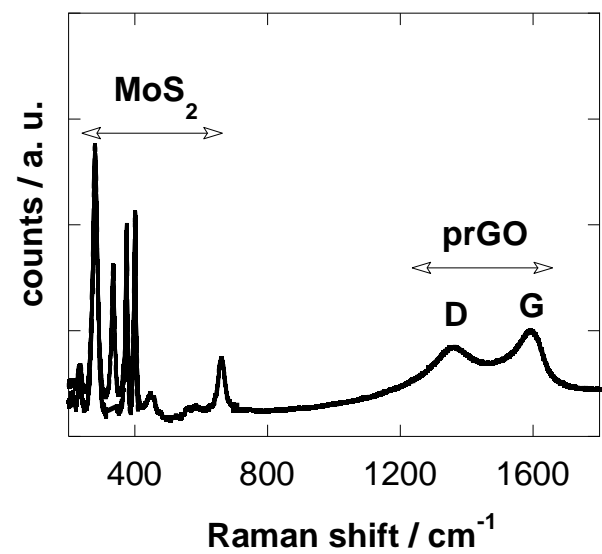

(C)

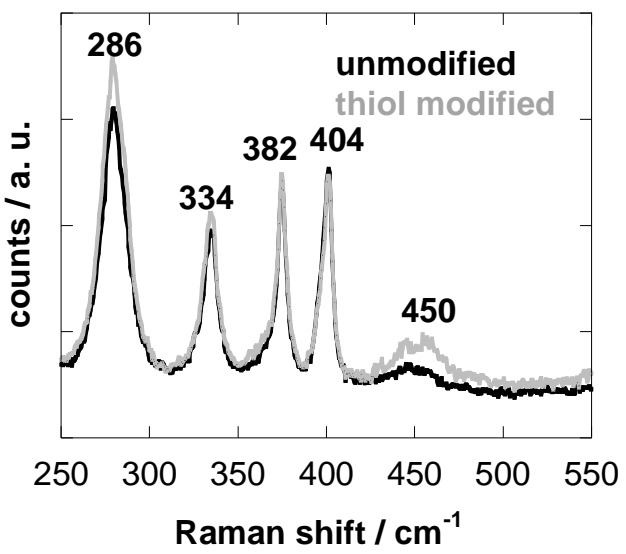

Figure 2: (A) Schematic presentation of the construction of an aptamer sensor for HPV-16; (B) Raman spectrum of $\mathrm{GC} / \mathrm{prGO} / \mathrm{MoS}_{2}$; (C) Raman region of unmodified $\mathrm{MoS}_{2}$ (black) and after functionalization with thiol ligands (laser excitation $473 \mathrm{~nm}$ ).

To examine further changes in the chemical composition of $\mathrm{GC} / \mathrm{prGO} / \mathrm{MOS}_{2}$ electrodes after surface modification, high resolution X-ray photoelectron spectroscopy (XPS) analysis was performed (Figure 3). The $\mathrm{Mo}_{3 \mathrm{~d}}$ XPS region (Figure 3A) shows bands at 229.2 and $232.2 \mathrm{eV}$ attributed to $\mathrm{Mo}^{4+} 3 \mathrm{~d}_{5 / 2}$ and $3 \mathrm{~d}_{3 / 2}$, respectively. The band at $235.5 \mathrm{eV}$ correlates to Mo-O oxide, mostly $\mathrm{MoO}_{3}\left(\mathrm{Mo}^{6+} 3 \mathrm{~d}_{5 / 2}\right)$ [50]. Functionalization with HS-PEG/MUA (mass ratio 
1/10) did not alter the XPS characteristics of the $\mathrm{Mo}_{3 \mathrm{~d}}$ band, indicating that the electronic environment around the Mo-atoms has not been modified.

The $\mathrm{S}_{2 \mathrm{p}}$ high resolution XPS spectrum of $\mathrm{prGO} / \mathrm{MoS}_{2}$ coated electrodes shows a contribution at $161.8 \mathrm{eV}\left(2 \mathrm{p}_{3 / 2}\right)$ and a smaller one at $163.05 \mathrm{eV}\left(2 \mathrm{p}_{1 / 2}\right)$, as reported by others [47]. In the case of thiolated interfaces, additional bands at 161.3, 162.7 and $164.2 \mathrm{eV}$ were observed and were attributed to the thiol moieties attached to the $\mathrm{prGO} / \mathrm{MoS}_{2}$. The band at $164.2 \mathrm{eV}$ ( $\sim 5$ at $\%$ ) is believed to be due to unbound physisorbed thiol molecules, while the bands at 161.3 and $162.7 \mathrm{eV}$ (total of 17 at \%) emerge from strongly chemisorbed thiol units.[47]

From the $\mathrm{C}_{1 \mathrm{~s}}$ high resolution spectra of $\mathrm{prGO} / \mathrm{MoS}_{2}$ before and after functionalization with thiol molecules, the presence of $\mathrm{COOH}$ and $\mathrm{C}-\mathrm{O}$ groups is clearly evidenced. The $\mathrm{C}_{1 \mathrm{~s}}$ core level XPS spectrum of $\mathrm{prGO} / \mathrm{MoS}_{2}$ displays the characteristic bands at $284.3 \mathrm{eV}\left(\mathrm{sp}^{2}\right.$ hybridized carbon), 285.0 (C-C/C-H), $286.1 \mathrm{eV}(\mathrm{C}-\mathrm{O})$ and $288.3 \mathrm{eV}(\mathrm{C}=\mathrm{O})$ [35], while the thiol-modified surface shows in addition a band at $291.6 \mathrm{eV}$ due to the incorporation of carboxylic acid groups and a slight increase in the band at $286.1 \mathrm{eV}$ due to the $\mathrm{C}-\mathrm{O}$ bands in thiol-PEG [51].

(A)

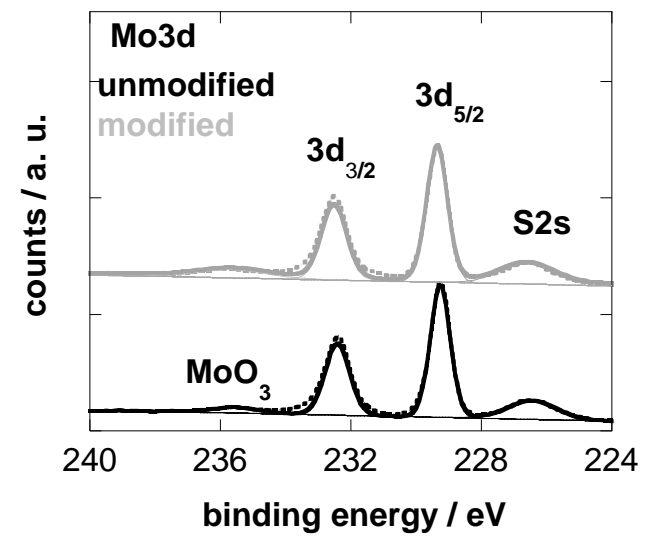

(B)

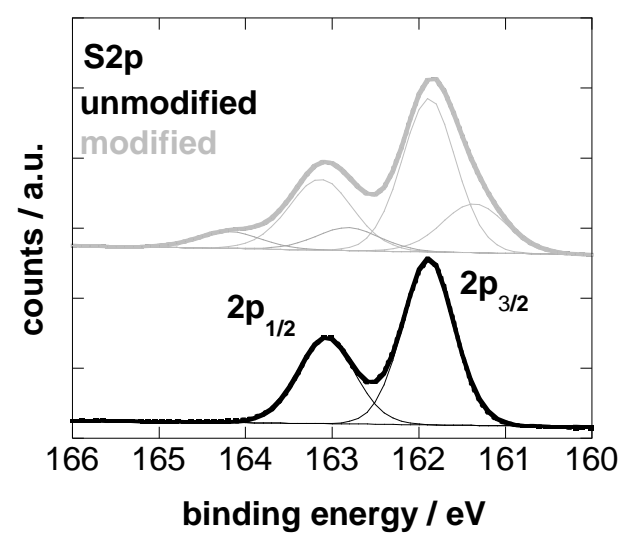

(C)

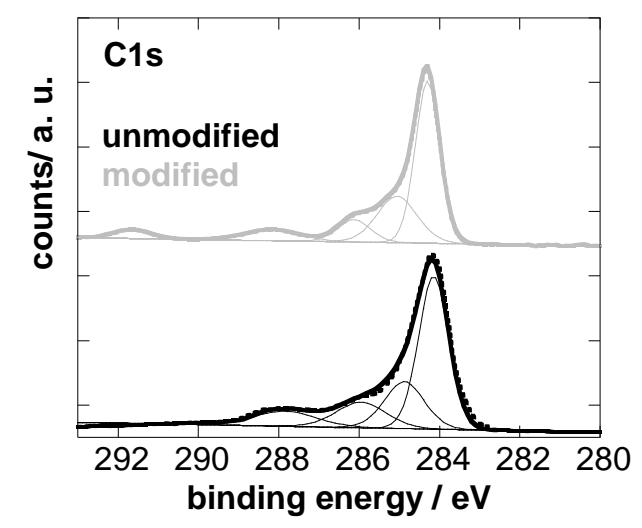


Figure 3: XPS analysis of $\mathrm{prGO} / \mathrm{MoS}_{2}$ electrodes before (black) and after thiolation (grey): (A) $\mathrm{Mo}_{3 \mathrm{~d}},\left(\right.$ B) $\mathrm{S}_{2 \mathrm{p}}$ and (C) $\mathrm{C}_{1 \mathrm{~s}}$ spectra.

\subsection{Electrochemical sensing of HPV-16 L1}

Cyclic voltammograms of MUA/HS-PEG modified GC/prGO/MoS 2 electrodes and HPV-16 L1 aptamer using $\left[\mathrm{Fe}(\mathrm{CN})_{6}\right]^{4-}$ as a redox probe were recorded (see SI, Figure S1). As $\left[\mathrm{Fe}(\mathrm{CN})_{6}\right]^{4-}$ proceeds through an inner-sphere electron transfer pathway, the electrode kinetic is highly sensitive to the surface termination of the electrode. A decrease in redox current density together with an increase from $\Delta \mathrm{E}=88 \mathrm{mV}$ to $99 \mathrm{mV}$ was observed for $\mathrm{GC} / \mathrm{prGO} / \mathrm{MoS}_{2}-\mathrm{L}_{1}$ when compared to the unmodified $\mathrm{GC} / \mathrm{prGO} / \mathrm{MoS}_{2}$ electrode. This is most likely due to increased electrostatic repulsion between the phosphate groups of RNA, as well as partial electron transfer blocking due to the presence of the large polyanionic RNA. Electrostatic repulsion between the $\mathrm{COOH}$ groups and $\left[\mathrm{Fe}(\mathrm{CN})_{6}\right]^{4-}$ is also believed to be the reason for the deceased current density on the $\mathrm{prGO} / \mathrm{MoS}_{2}-\mathrm{COOH}$ interface. Interestingly, this electrode showed an improved $\Delta \mathrm{E}=79 \mathrm{mV}$ when compared to the unmodified $\mathrm{GC} / \mathrm{prGO} / \mathrm{MoS}_{2}$ electrode indicating faster electron transfer. The reasons for this phenomena are currently not well understood, but are intrinsically linked to the surface chemistry of the interface. To rule out electrostatic effects, the electron transfer of $\left[\mathrm{Ru}\left(\mathrm{NH}_{3}\right)_{6}\right]^{3+}$, a positively charged outer-sphere redox species was investigated, where the electrode kinetics is surface insensitive. Using the positively charged $\left[\mathrm{Ru}\left(\mathrm{NH}_{3}\right)_{6}\right]^{3+}$ redox species, a decrease in redox current density was likewise observed with however no noticeable change in $\Delta \mathrm{E}$, which remained in all cases at $\Delta \mathrm{E}=93 \mathrm{mV}$. It might be speculated that electroactive $\left[\mathrm{Ru}\left(\mathrm{NH}_{3}\right)_{6}\right]^{3+}$ binds to RNA through electrostatic interactions with the phosphate backbone maintaining the electron transfer rate [52].

To determine whether the $\mathrm{GC} / \mathrm{prGO} / \mathrm{MoS}_{2}-\mathrm{L}_{1}$ electrode can analyze quantitatively and selectively HPV recombinant HPV-16 L1 proteins, the change in peak current density upon addition of increasing concentrations of HPV-16 L1 using differential pulse voltammetry (DPV) was measured (Figure 4A). A linear relationship in the range of $0.2-2 \mathrm{ng} \mathrm{mL}^{-1}$ (5.3 pM-35.3 pM) HPV-16 L1 proteins is recorded with a correlation coefficient of 0.9998 according to $\mathrm{j}\left(\mathrm{mA} \mathrm{cm}^{-2}\right)=2.14-0.83[\mathrm{HPV}-16 \mathrm{~L} 1]\left(\mathrm{ng} \mathrm{mL}^{-1}\right)$ (Figure 4B). The detection limit was determined to be about $0.1 \mathrm{ng} \mathrm{mL}^{-1}(1.75 \mathrm{pM})$ for HPV-16 L1 from five blank noise signals (95\% confidential level). Indeed, it was reported that the RNA L1 aptamer without the $\mathrm{NH}_{2}$-TTT-TTT units added at the 3' end has a very high affinity with a low $\mathrm{K}_{\mathrm{d}}=0.05 \mathrm{pM}$ [22]. 
This indicates that the sensor is in the ligand-depletion regime, where experimental conditions, including probe density and surface area as well as sample volume are important parameters [53].

In the case of $\mathrm{GC}$ electrodes odified with prGO or $\mathrm{MoS}_{2}$ only, the current density scaled linearly with the concentration of HPV-16 L1 proteins with a decreased sensitivity according to $\mathrm{j}\left(\mathrm{mA} \mathrm{cm}^{-2}\right)=1.8-0.62[\mathrm{HPV}-16 \mathrm{~L} 1]\left(\mathrm{ng} \mathrm{mL}^{-1}\right)$ for $\mathrm{GC} / \mathrm{prGO}-\mathrm{L}_{1}$ and $\mathrm{j}\left(\mathrm{mA} \mathrm{cm}^{-2}\right)=21.8-$ 0.42 [HPV-16 L1] $\left(\mathrm{ng} \mathrm{mL}^{-1}\right)$ for $\mathrm{GC} / \mathrm{MoS}_{2}-\mathrm{L}_{1}$ with a decreased linear range (see SI, Figure S2).

To validate in addition that one layer of $\mathrm{prGO} / \mathrm{MoS}_{2}$ is favorable for sensing, the sensitivity of $\mathrm{GC} / \mathrm{prGO} / \mathrm{MoS}_{2}-\mathrm{L}_{1}$ electrode formed by two and three $\mathrm{prGO} / \mathrm{MoS}_{2}$ layers was evaluated in addition (see SI, Figure S3). In the case of the $\mathrm{GC} / \mathrm{prGO} / \mathrm{MoS}_{2}-\mathrm{L}_{1}$ electrode formed using two prGO/MoS 2 layers, a sensitivity according to $\mathrm{j}\left(\mathrm{mA} \mathrm{cm}^{-2}\right)=2.35-0.76$ [HPV-16 L1] (ng $\mathrm{mL}^{-1}$ ) was determined; in the case of three layers the sensitivity was even lower with $\mathrm{j}(\mathrm{mA}$ $\left.\mathrm{cm}^{-2}\right)=2.07-0.65[\mathrm{HPV}-16 \mathrm{~L} 1]\left(\mathrm{ng} \mathrm{mL}^{-1}\right)$, both being lower that for the electrode formed with one layer.

As the density of the RNA L1 aptamer on the sensor might influence the characteristics of the sensor, the ratio of MUA/HS-PEG was changed as well as the amount of 3'- $\mathrm{NH}_{2}$ modified aptamer. Table 1 summarizes the results of this optimization process. Using a MUA/HSPEG ratio of $10 / 1$ and a $5 \mu \mathrm{M}$ aptamer solution showed the best sensing performance.

(A)

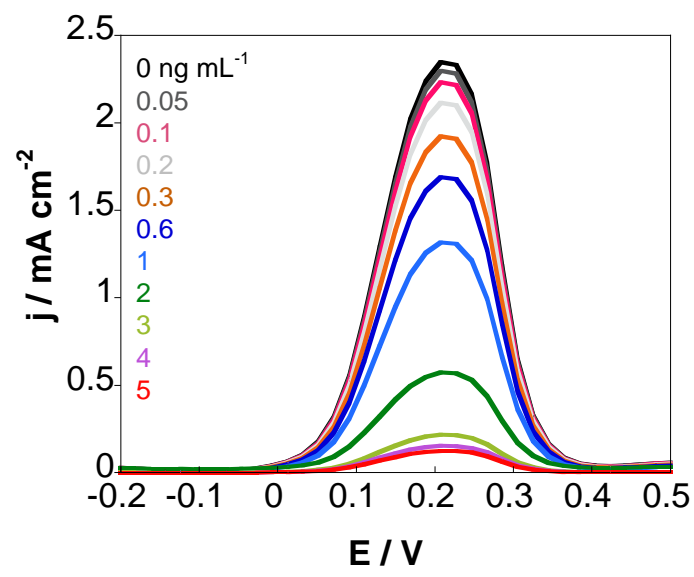

(B)

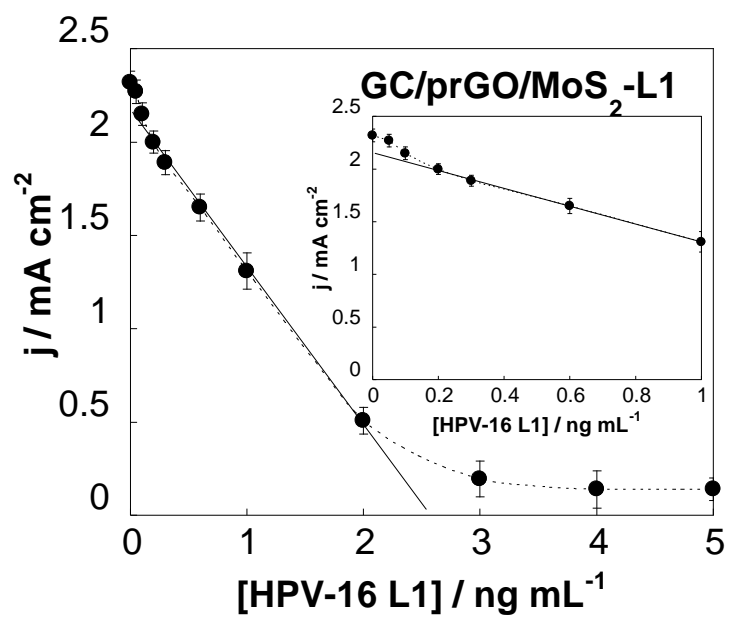


(C)

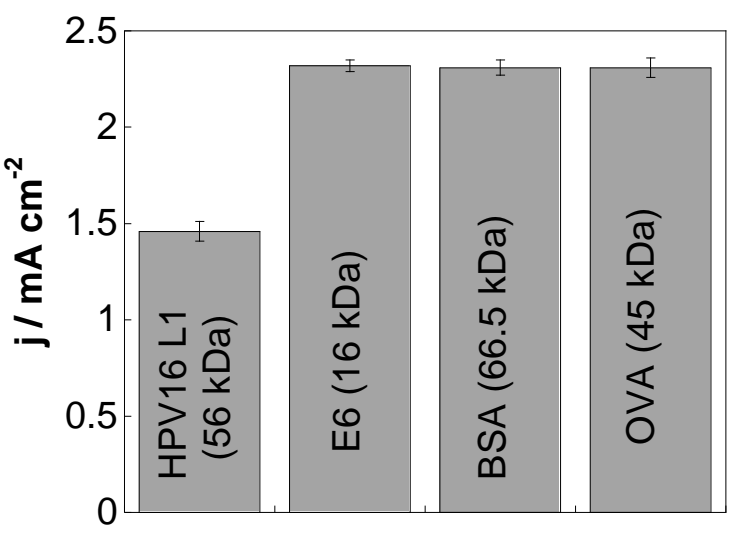

different proteins
(D)

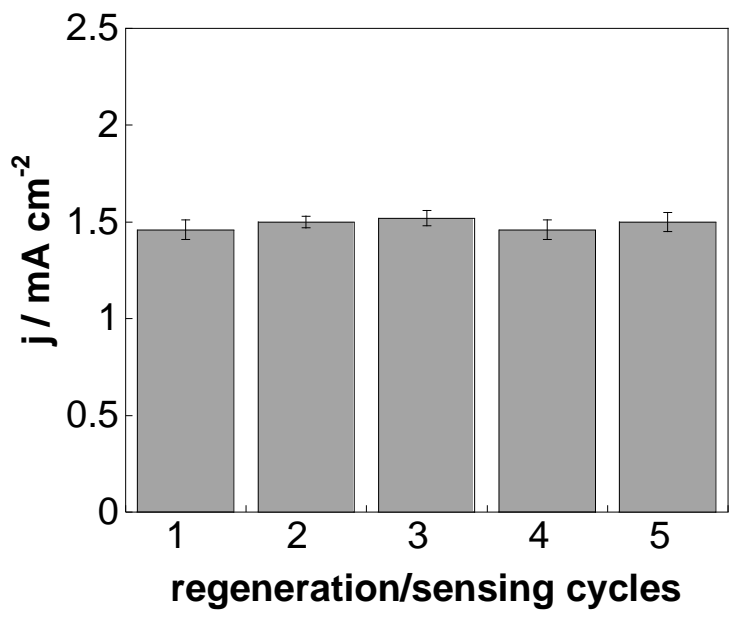

Figure 4: (A) Differential pulse voltammograms recorded on $\mathrm{GC} / \mathrm{prGO} / \mathrm{MoS}_{2}-\mathrm{L}_{1}$ in $\left[\mathrm{Fe}(\mathrm{CN})_{6}\right]^{4-}(10 \mathrm{mM}) / \mathrm{PBS}(0.1 \mathrm{M})$ upon addition of HPV-16 L1; (B) Change of peak current density as a function of HPV-16 L1 concentration for GC/prGO/MoS ${ }_{2}-\mathrm{L}_{1}$, error bars were evaluated from three different sensors (inset: zoom to lower concentrations); (C) Current density response of $\mathrm{GC} / \mathrm{prGO} / \mathrm{MoS}_{2}-\mathrm{L}_{1}$ electrodes to HPV-16 L1 $\left(1 \mathrm{ng} \mathrm{mL}^{-1}\right)$ and different interfering species at $100 \mathrm{ng} \mathrm{mL}^{-1}$; (D) Influence of the regeneration step on the oxidation current density detected on $\mathrm{GC} / \mathrm{prGO} / \mathrm{MoS}_{2}-\mathrm{L}_{1}$ in $\left[\mathrm{Fe}(\mathrm{CN})_{6}\right]^{4-}(10 \mathrm{mM}) / \mathrm{PBS}(0.1 \mathrm{M})$ upon addition of HPV-16 L1 $\left(1 \mathrm{ng} \mathrm{mL}^{-1}\right)$.

Table 1: Sensor optimization in terms of density of $\mathrm{COOH}$ function (by controlling the MUA/HS-PEG ratio) and the amount of immobilized aptamer on the $\mathrm{GC} / \mathrm{prGO} / \mathrm{MoS}_{2}$ surface.

\begin{tabular}{lcccc}
\hline sensor & MUA/HS-PEG & $\begin{array}{c}3^{\prime}-\mathrm{NH}_{2} \text {-aptamer } \\
(\mu \mathrm{M})\end{array}$ & $\begin{array}{c}\text { LOD } \\
(\mathrm{pM})\end{array}$ & $\begin{array}{c}\text { Linear range } \\
(\mathrm{pM})\end{array}$ \\
\hline 1 & $1 / 10$ & 5 & 10.3 & $11.2-21.3$ \\
2 & $5 / 10$ & 5 & 5.6 & $6.3-22.6$ \\
$\mathbf{3}$ & $\mathbf{1 0 / 1}$ & $\mathbf{5}$ & $\mathbf{3 . 5}$ & $\mathbf{5 . 3 - 3 5 . 3}$ \\
4 & $20 / 1$ & 5 & 5.3 & $7.3-30.6$ \\
5 & $20 / 1$ & 2 & 5.4 & $10.2-22.6$ \\
6 & $20 / 1$ & 10 & 8.4 & $6.4-22.9$ \\
\hline
\end{tabular}

Table 2 compares the performance of the developed aptasensor to other electrochemical based HPV sensors reported in the literature. The sensor performs well comparted to several 
DNA based HPV sensors. Compared to the DNA sensor proposed by Wang using SWCNTs modified with gold nanoparticles [8], the performance of the aptasensor is more ordinary. Compared to the other aptamer sensor for HPV by Tran [54], considerable improvements were obtained making it thus an interesting alternative to DNA based HPV sensors. The advantages are associated with the ease of sensor fabrication together with the use of stable and specific aptamer chemistry, making the sensor concept easily adaptable to other HPV strands.

Table 2: Performance of different electrochemical based HPV sensing platforms

\begin{tabular}{|c|c|c|c|c|c|c|}
\hline Method & Interface & analyte & modification & LOD & Linear range & Ref. \\
\hline SWV & GC-polymer & HPV-16 & HVP-16 L1 & $50 \mathrm{nM}$ & - & [55] \\
\hline DPV & Au/L-cysteine & HPV-16 & HPV-16 DNA & $18.13 \mathrm{nM}$ & $18.7-250 \mathrm{nM}$ & [9] \\
\hline $\mathrm{CV}$ & $\mathrm{Au} / \mathrm{ss}-\mathrm{DNA}$ & HPV-L1 gene & HPV DNA & $3.8 \mathrm{nM}$ & $12.5-350 \mathrm{nM}$ & {$[6]$} \\
\hline SWV & Carbon/chitosan & HPV-16 & AQ-PNA & $4 \mathrm{nM}$ & 4-12 nM & [7] \\
\hline EIS & G-PANI & HPV-16 & AQPC-PNA & $2.3 \mathrm{nM}$ & $10-200 \mathrm{nM}$ & {$[15]$} \\
\hline EIS & $\begin{array}{l}\text { GC/ carbon nano- } \\
\text { onions/PAA }\end{array}$ & HPV-16 & $\begin{array}{l}\text { HPV-16 E7 } \\
\text { DNA }\end{array}$ & $0.54 \mathrm{nM}$ & $0.54-20 \mathrm{nM}$ & [19] \\
\hline $\mathrm{CV}$ & Electrode array & $\begin{array}{l}\text { HPV-16 } \\
\text { HPV-45 }\end{array}$ & $\begin{array}{l}\text { HPV DNA } \\
\text { TMB as } \\
\text { substrate for } \\
\text { HRP-labelled } \\
\text { reporter DNA }\end{array}$ & $\begin{array}{l}490 \mathrm{pM} \\
(\mathrm{HPV}-16) \\
11 \mathrm{pM} \\
(\mathrm{HPV}-45)\end{array}$ & $0.1-150 \mathrm{nM}$ & [10] \\
\hline CV/SWV & $\begin{array}{l}\text { Pt/polyaniline/ } \\
\text { MWCNTs }\end{array}$ & HPV-16 & $\begin{array}{l}\mathrm{L} 1 \text { peptide } \\
\text { aptamer }\end{array}$ & $490 \mathrm{pM}$ & $10-80 \mathrm{nM}$ & {$[54]$} \\
\hline DPV & prGO-MoS ${ }_{2}$ & HPV-16 L1 & $\begin{array}{l}\text { RNA L1 } \\
\text { aptamer }\end{array}$ & $1.75 \mathrm{pM}$ & 3.5-35.3 pM & $\begin{array}{l}\text { this } \\
\text { work }\end{array}$ \\
\hline $\mathrm{CA}$ & & HPV-16 & $\begin{array}{l}\text { Magnetic beads- } \\
\text { DNA }\end{array}$ & $1 \mathrm{pM}$ & $1 \mathrm{pM}-1 \mathrm{nM}$ & [56] \\
\hline $\begin{array}{l}\text { DPV (red. } \\
\mathrm{Hg}^{2+} \text { ) }\end{array}$ & GCE & HPV-18 & $\mathrm{Hg}^{2+}$ - thymine & $12 \mathrm{fM}$ & - & [57] \\
\hline EIS & $\begin{array}{l}\text { GCE/ G/Au NR } \\
\text { /polythionine }\end{array}$ & HPV & DNA & $40 \mathrm{fM}$ & $100 \mathrm{fM}-100 \mathrm{pM}$ & [58] \\
\hline EIS & $\begin{array}{l}\text { SWCNT/Au } \\
\text { NPS }\end{array}$ & HPV-16 & HPV-16 DNA & $1 \mathrm{aM}$ & $1 \mathrm{aM}-1 \mathrm{pM}$ & [8] \\
\hline
\end{tabular}

AQ: anthraquinone-labeled, CA: chronoamperometry, G: graphene, TMB: 3,3',5,5'-tetramethylbenzidine, PAA: 4aminophenylacetic acid; PANI: polyaniline, polymer=poly(5-hydroxyl-1,4-naphthoquinon-co-5-hydroxyl-2-carboxyethyl1,4-naphthoquinine), PC: pyrrolidinyl ; SWCNT: single walled carbon nanotubes; SWV: square wave voltammetry 
To evaluate the specificity of the sensor for HPV-16 L1, the current density response of $\mathrm{GC} / \mathrm{prGO} / \mathrm{MoS}_{2}-\mathrm{L}_{1}$ to different protein solutions of ten times the concentration of HPV-16 L1 was determined (Figure 4C). No change in current density was observed either for ovalbumin (OVA) or human serum albumin (HSA), proteins of comparable size. Most important, HPV16 E6 did not show any change in current density response as well, underlining the good selectivity of this RNA aptamer modified interface for HPV-16 L1.

The reproducibility of the electrode fabrication and use for HPV-16 L1 sensing is expressed in terms of the relative standard deviation, and is found to be $9.3 \%$ at a HPV-16 L1 concentration of $1 \mathrm{ng} \mathrm{mL} \mathrm{m}^{-1}$.

The long-term stability of the sensor exhibited a loss of 5\% when tested in HPV-16 L1 (1 ng $\mathrm{mL}^{-1}$ ) after the electrode was stored at $4^{\circ} \mathrm{C}$ for a month.

The reusability of the electrode was in addition evaluated by determining the current density response of $\mathrm{GC} / \mathrm{prGO} / \mathrm{MoS}_{2}-\mathrm{L}_{1}$ to $\mathrm{HPV}-16 \mathrm{~L} 1\left(1 \mathrm{ng} \mathrm{mL}{ }^{-1}\right)$ after immersion for $30 \mathrm{~min}$ in aqueous $\mathrm{H}_{2} \mathrm{SO}_{4}(0.5 \mathrm{M})$. Figure 4D indicates that this cleaning step does not influence the sensitivity of the measurements.

\subsection{Sensing in spiked human serum and saliva samples}

To test the performance of the developed sensor for the analysis of bodily liquids, human serum and saliva samples were spiked with a known concentration of HPV-16 L1 (1 ng mL $\left.\mathrm{mL}^{-1}\right)$ and the electrochemical signal was determined using the $\mathrm{GC} / \mathrm{prGO} / \mathrm{MoS}_{2}-\mathrm{L}_{1}$ electrode. Figure 5 compares the differential pulse voltammograms of PBS, human serum and human saliva solutions spiked with HPV-16 L1 $\left(1 \mathrm{ng} \mathrm{mL}^{-1}\right)$. While the half peak width of the redox peak is larger in serum and saliva solutions spiked with HPV-16 L when compared to PBS, the peak current density remains unaffected. Using the calibration curve in Figure 4B, HPV$16 \mathrm{~L} 1$ concentrations of $1.02 \pm 0.5 \mathrm{ng} \mathrm{mL}^{-1}$ and $1.03 \pm 0.5 \mathrm{ng}$ were determined in serum and saliva, respectively, in good agreement with the results in PBS, making the sensor well adapted for sensing in biological media.

To see if the aptasensor responds to different HPV-16 L1 concentrations in a correct manner, the human serum and salvia samples were spiked with different HPV-16 L1 concentrations. Table 3 displays the total HPV-16 -L1 concentrations determined from the current density responses. 


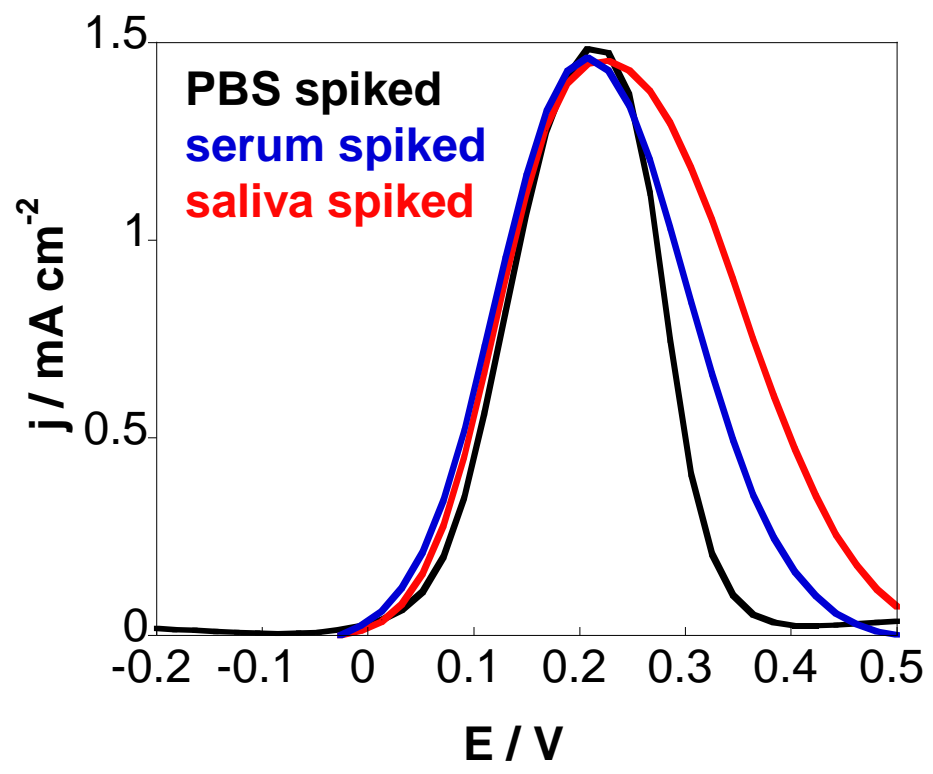

Figure 5: Differential pulse voltammograms recorded on $\mathrm{GC} / \mathrm{prGO} / \mathrm{MoS}_{2}-\mathrm{L}_{1}$ in $\left[\mathrm{Fe}(\mathrm{CN})_{6}\right]^{4-}$ (10 mM)/ PBS (0.1 M, pH 7.4, black), human serum (blue) and human saliva (red) spiked with $1 \mathrm{ng} \mathrm{mL} \mathrm{L}^{-1} \mathrm{HPV}-16 \mathrm{~L} 1$.

Table 3: Analysis of HPV-16 L1 spiked human serum and human saliva samples using the developed electrochemical sensor.

\begin{tabular}{|l|c|c|}
\hline \multicolumn{1}{|c|}{ sample } & $\begin{array}{c}\text { HPV-16 L1 } \\
{\left[\mathrm{ng} \mathrm{mL}^{-1}\right]}\end{array}$ & recovery \\
\hline Human serum & $\mathbf{0}$ & \\
\hline human serum+0.5 $\mathrm{ng} \mathrm{mL}^{-1}$ & $0.55 \pm 0.1$ & $90.9 \%$ \\
\hline human serum +1 $\mathrm{ng} \mathrm{mL}^{-1}$ & $1.02 \pm 0.1$ & $98.0 \%$ \\
\hline human serum +2 $\mathrm{ng} \mathrm{mL}^{-1}$ & $2.1 \pm 0.1$ & $95.2 \%$ \\
\hline Human saliva & $\mathbf{0}$ & \\
\hline human saliva $+0.5 \mathrm{ng} \mathrm{mL}^{-1}$ & $0.48 \pm 0.1$ & $104.2 \%$ \\
\hline human saliva $+1 \mathrm{ng} \mathrm{mL}^{-1}$ & $1.03 \pm 0.1$ & $97.1 \%$ \\
\hline human saliva $+2 \mathrm{ng} \mathrm{mL}^{-1}$ & $1.9 \pm 0.1$ & $105.3 \%$ \\
\hline
\end{tabular}

\section{Conclusion}

We have demonstrated in this work the interest a layer-by-layer modified glassy carbon electrodes using porous reduced graphene oxide $(\mathrm{rGO})$ and molybdenum sulfide $\left(\mathrm{MoS}_{2}\right)$ for electrochemical based applications. The good electronic properties and large surface area of both materials interacting strongly with each other are believed to be responsible for the enhanced electrochemical response. This interface was successfully used to construct a HPV$16 \mathrm{~L} 1$ protein specific biosensor. For this, an $\mathrm{NH}_{2}$ functionalized RNA aptamer, Sc5-c3, was immobilized onto the electrode surface through covalent linking to the carboxyl groups 
integrated onto the electrode surface using a mixture of mercaptoundecanoic acid and a pegylated thiol. From XPS analysis, it could be concluded that some of the thiolated compounds are indeed chemisorbed onto the electrode, while a smaller part remains physisorbed. Using differential pulse voltammetry (DPV) and $\left[\mathrm{Fe}(\mathrm{CN})_{6}\right]^{4-}$ as a redox mediator, HPV-16 L1 protein can be analyzed in the concentration range of $0.2-2 \mathrm{ng} \mathrm{mL}^{-1}$ with a detection limit of $0.1 \mathrm{ng} \mathrm{mL} \mathrm{m}^{-1}$. The aptamer proved in addition to be highly specific to HPV-16 L1, making the approach of interest for the screening of biological samples. Furthermore, spiking human serum as well as saliva with HPV-16 L1 protein allowed a correct determination of the L1 protein concentration. We thus believe that this sensing approach is a competitive alternative to the currently prevailing nucleic-hybridization assays.

\section{Acknowledgements}

Financial support from the Centre National de la Recherche Scientifique (CNRS), the University of Lille, the Hauts-de-France region, the CPER "Photonics for Society", and the joint support of Agence Nationale de la Recherche (ANR) through FLAG-ERA JTC 2015Graphtivity project are acknowledged. The EU is thanked for the support through the Marie Sklodowska-Curie action (H2020-MSCA-RISE-2015, PANG-690836). KB wants to thank you EU for a Marie-Curie fellowship. The Fonds Européen de Développement Régional (FEDER), CNRS, Région Nord Pas-de-Calais and Ministère de l'Education Nationale de l'Enseignement Supérieur et de la Recherche are acknowledged for funding of XPS/LEIS/ToF-SIMS spectrometers within the Pôle Régional d'Analyses de Surface.

\section{References}

[1] M. Schriffman, N. Wentzensen, Human paollomavirus infection and the multistage carcinogenesis of cervial cancer. Cancer Epidemiol Biomarkeres Prev. 22 (2013) 553560 .

[2] M. de Villiers, C. Fauquet, T.R. Broker, H.-U. Bernard, H. zur Hausen, Classification of papillomaviruses. Virology 324 (2004) 17-27.

[3] J.C. Graham, H. Zarbl, Use of cell-SELEX to generate DNA aptamers as molecualr probes of HPV associated cervical cancer cells. PloS One 7 (2013) e36103.

[4] A.L.P. Abreu, R.P. Souza, F. Gimenes, M.E.L. Consolaro, A review of methods for detect human Papillomavirusinfection. Virology Journal 9 (2012) 262.

[5] http://www.thehpvtest.com/ /media/5C4BD0982BED4E3788F65B36AF829AAD.ashx.

[6] N. Nasirizadeh, H.R. Zare, M.H. Pournaghi-Azar, M.S. Hejazi, Introduction of hematoxylin as an electroactive label for DNA biosensors and its employment in detection of target DNA sequence and single-base mismatch in human papilloma virus corresponding to oligonucleotide, Biosens. Bioelectron. 26 (2011) 2638-2644.

[7] S. Jampasa, W. Wonsawat, N. Rodthongkum, W. Siangproh, P. Yanatatsaneejit, T. Vilaivan, O. Chailapakul, Electrochemical detection of human papillomavirus DNA 
type 16 using a pyrrolidinyl peptide nucleic acid probe immobilized on screen-printed carbon electrodes. Biosens. Bioelectron. 54 (2014) 428-434.

[8] S. Wang, L. Li, H. Jin, T. Tang, W. Bao, S. Huang, J. Wang, Electrochemical detection of hepatitis B and papilloma virus DNAs using SWCNT array coated with gold nanoparticles. Biosens. Bioelectron. 41 (2013) 205-210.

[9] D.S. Campos-Ferreira, G.A. Nascimento, E.V.M. Souza, M. Souto-Maior, M.S. Arrunda, D.M.L. Zanforlin, M.H.F. Ekert, D. Bruneska, J.L. Lima-Filhor, Electrochemical DNA biosensor for human papillomavirus 16 detection in real samples. Anal. Chim. Acta 804 (2013) 258-263.

[10] L. Civit, A. Fragoso, C.K. O'Sullivan, Electrochemical biosensor for the multiplexed detection of human papillomavirus genes. Biosens. Bioelectron. 26 (2010) 16841687.

[11] I.A.M. Frías, K.Y.P.S. Avelino, R.R. Silva, C.A.S. Andrade, M.D.L. Oliveira, Trends in Biosensors for HPV: Identification and Diagnosis. J.of Sensors 913640, (2015) 116.

[12] N. Azizah, U. Hashim, S. Nadzirah, A.R. Ruslinda, Rapid and sensitive strategy for Human Papillomavirus (HPV) detection using a gene-based DNA nanobiosensor. Biomedical Engineering and Sciences (IECBES), IEEE Conference (2014) 960-963,

[13] L. Civit, A. Fragoso, S. Holters, M. Durst, C.K. O'Sullivan, Electrochemical genosensor array for the simultaneous detection of multiple high-risk human papillomavirus sequences in clinical samples. Anal. Chim. Acta 715 (2012) 93-98.

[14] R.E. Sabzi, B. Sehatnia, M.H. Pournaghi-Azar, M.S. Hejazi, Electrochemical detection of human papilloma virus (HPV) target DNA using MB on pencil graphite electrode. J. Iran. Chem. Soc. 5 (2008) 476-483.

[15] P. Teengam, W. Siangproh, A. Tuantranont, C.S. Henry, T. Vilaivan, O. Chailapakul, Electrochemical paper-based peptide nucleic acid biosensor for detecting human papillomavirus. Anal. Chim. Acta 952 (2017) 32-40.

[16] D.S. Campos-Ferreira, E.V.M. Souza, G.A. Nascimento, D.M.L. Zanforlin, M.S. Arruda, M.F.S. Beltrao, A.L. Melo, D. Bruneska, J.L. Lima-Filhor, Electrochemical DNA biosensor for the detection of human papillomavirus E6 gene inserted in recombinant plasmid. Arab. J. Chem. 9 (2016) 443-450.

[17] M. Bartosika, H. Durikova, B. Vojtesek, M. Anton, E. Jandakova, R. Hrstka, Electrochemical chip-based genomagnetic assay for detection of high-risk human papillomavirus DNA. Biosens. Bioelectron. 83 (2016) 300-305.

[18] D.P. .Valencia, L.M.F. Dantas, A. Lara, J. García, Z. Z.Rivera, J. J.Rosas, M. Bertottia, Development of a bio-electrochemical immunosensor based on the immobilization of SPINNTKPHEAR peptide derived from HPV-L1 protein on a gold electrode surface. J. Electroanal. Chem. 770 (2016) 50-55.

[19] J.P. Bartolome, L. Echegoyen, A. Fragoso, Reactive Carbon Nano-Onion Modified Glassy Carbon Surfaces as DNA Sensors for Human Papillomavirus Oncogene Detection with Enhanced Sensitivity. Anal. Chem. 87 (2015) 6744-6751.

[20] A. Vasilescu, Q. Wang, M. Li, R. Boukherroub, S. Szunerits, Aptamer-Based Electrochemical Sensing of Lysozyme. Chemosensors 4 (2016) 10.

[21] A.G. Leija-Montoya, M. Benitez-Hess, L. Alvarez-Salas, 2016., Application of Nucleic acid Aptamres to Viral Deteciton and Inhibition. In Nuclei acids-From basic Aspects to Laboratry Tool, in: M.L. Larramendy, S. Soloneski (Eds.) Biochemistry, Genetics and Molecular Biology » "Nucleic Acids - From Basic Aspects to Laboratory Tools, IntTch, Ed. 2016. 
[22] A.G. Leija-Montoya, M. Benitez-Hess, J.D. Toscano-Gaibay, L.M. Alvarez-Salas, Characterization of an RNA aptamer against HPV-16 L1 virus-like particles. Nucleic Acid Ther. 24 (2014) 344.

[23] A. Walcarius, Electrocatalysis, sensors and biosensors in analytical chemistry based on ordered mesoporous and macroporous carbon-modified electrodes. Trends Anal. Chem. 38 (2012) 79-97.

[24] F. Chekin, V.M. Dhavale, S. Kurungot, R. Boukherroub, S. Szunerits, Reduced Graphene Oxide Modified Electrodes for Sensitive Sensing of Gliadin in Food Samples. ACS Sensors 1 (2016) 1462-1470.

[25] S. Han, D. Wu, S. Li, F. Zhang, Porous graphene materials for advanced electrochemical energy storage and conversion devices. Adv. Mater. 26 (2014) 849-864.

[26] L. Jiang, Z. Fan, Design of advanced porous graphene materials: from graphene nanomesh to 3D architectures. .Nanoscale 6 (2014) 1922.

[27] G. Li, H. Huo, C. Xu, Ni0.31Co0.69S2 nanoparticles uniformly anchored on a porous reduced graphene oxide framework for a high-performance non-enzymatic glucose sensor. J. Mater. Chem. A 3 (2015) 4922.

[28] Y. Huang, J. Guo, Y. Kang, Y. Ai, C.M. Li, Two dimensional atomically thin $\mathrm{MoS}_{2}$ nanosheets and their sensing applications. Nanoscale 7 (2015) 19358.

[29] S. Su, X. Xiaoyan Han, Z. Lu, W. Liu, D. Zhu, J. Chao, C. Fan, L. Wang, S. Song, L. Weng, L. Wang, Facile Synthesis of a $\mathrm{MoS}_{2}-$ Prussian Blue Nanocube NanohybridBased Electrochemical Sensing Platform for Hydrogen Peroxide and Carcinoembryonic Antigen Detection. ACS Appl. Mater. Interfaces 9 (2017) 1277312781.

[30] S. Su, W. Cao, C. Zhang, X. Han, J. Yu, H. Zhu, J. Chao, C. Fana, L. Wang, Improving performance of MoS2-based electrochemical sensors by decorating noble metallic nanoparticles on the surface of $\mathrm{MoS}_{2}$ nanosheet RSC Adv. 6 (2016) 7661476620

[31] K.-J. Huang, L. Wang, J. Li, Y.-M. Liu, Electrochemical sensing based on layered $\mathrm{MoS}_{2}$-graphene composites. Sens. Actuators B 178 (2013) 671-677.

[32] C.N.R. Rao, K. Gopalakrishnan, U. Maitra, Comparative Study of Potential Applications of Graphene, $\mathrm{MoS}_{2}$, and Other Two-Dimensional Materials in Energy Devices, Sensors, and Related Areas. ACS Appl. Mater. Interfaces 7 (2015) 78097832.

[33] K. Pramoda, K. Moses, U. Maitra, C.N.R. Rao, Superior Performance of a $\mathrm{MoS}_{2}-\mathrm{RGO}$ Composite and a Borocarbonitride in the Electrochemical Detection of Dopamine, Uric Acid and Adenine. Electroanalysis 27 (2015) 1892-1898.

[34] H.-U. Kim, H.Y. Kim, A. Kulkarni, C. Ahn, Y. Jin, Y. Kim, K.-N. Lee, M.-H. Lee, T. Kim, A sensitive electrochemical sensor for in vitro detection of parathyroid hormone based on a MoS ${ }_{2}$-graphene composite. Sci. Rep. 6 (2016) 34587.

[35] F. Chekin, F. Teodorescu, Y. Coffinier, G.-H. Pan, A. Barras, R. Boukherroub, S. Szunerits, MoS2/reduced graphene oxide as active hybrid material for the electrochemical detection of folic acid in human serum. Biosens. Bioelectron. 85 (2016) 807-813.

[36] S.K. Singh, V.M. Dhavale, R. Boukherroub, S. Kurungot, S. Szunerits, N-doped porous reduced graphene oxide as an efficient electrode material for high performance flexible solid-state supercapacitor. Appl Mater. Today 5 (2016) 2016.

[37] K. Kalantar-zadeh, J.Z. Ou, Biosensors Based on Two-Dimensional MoS 2 . ACS Sensors 1 5-16. 
[38] T. Wang, R. Zhu, J. Zhuo, Z. Zhu, Y. Shao, M. Li, Direct Detection of DNA below ppb Level Based on Thionin-Functionalized Layered $\mathrm{MoS}^{2}$ Electrochemical Sensors. Anal. Chem. 86 (2014) 12064-12069.

[39] T. Wang, H. Zhu, J. Zhuo, Z. Zhu, O. Papakonstantinous, G. Lubarsjy, J. Lin, M. Li, Biosensor Based on Ultrasmall $\mathrm{MoS}_{2}$ Nanoparticles for Electrochemical Detection of $\mathrm{H}_{2} \mathrm{O}_{2}$ Released by Cells at the Nanomolar Level. Anal. Chem. 85 (2013) 1028910295.

[40] T. Wang, K. Du, W. Liu, J. Zhang, M. Li, Electrochemical Sensors Based on Molybdenum Disulfide Nanomaterials. Electroanalysis 27 (2015) 2091-2097.

[41] S . Wu, Z. Zeeng, Q. He, Z. Wang, S.J. Wang, D. Y., Z. Yin, X. Sun, W. Chen, H. Zhang, Electrochemically Reduced Single-Layer $\mathrm{MoS}_{2}$ Nanosheets: Characterization, Properties, and Sensing Applications. Small 8 (2012) 2264-2270.

[42] D. Sarkar, W. Liu, X. Xie, A.C. Anselmo, S. Mitrogoti, K. Banerjee, MoS2 FieldEffect Transistor for Next-Generation Label-Free Biosensors. ACS Nano 8 (2014) 3992-4003.

[43] A. Vasilescu, S. Boulahneche, F. Chekin, S. Gaspar, M.S. Medjram, A.A. Diagne, S.K. Singh, S. Kurungot, R. Boukherroub, S. Szunerits, Porous reduced graphene oxide modified electrodes for the analysis of protein aggregation. Part 1: Lysozyme aggregation at $\mathrm{pH} 2$ and 7.4 Electrochim. Acta 254 (2017) 375-383.

[44] X. Chen, N.C. Berner, C. Backes, G.S. Duesberg, A.R. McDonald, Functionalization of Two-Dimensional $\mathrm{MoS}_{2}$ : On the Reaction Between $\mathrm{MoS}_{2}$ and Organic Thiols. Angew. Chem. Int. Ed. 55 (2016) 5803-5808

[45] S.S. Chou, M. De, J. Kim, N. Byun, C. Dykstra, J. Yu, J. Huang, V.P. Dravid, Ligand conjugation of chemically exfoliated $\mathrm{MoS}_{2}$. J. Am. Chem. Soc. 135 (2013) 4584-4587.

[46] S. Presolski, M. Pumera, Covalent functionalization of $\mathrm{MoS}_{2}$. Mat. Today 196 (2016) 140-145.

[47] Q. Ding, K.J. Czech, Y. Zhao, R.J. Hamers, J.C. Wright, S. Jin, Basal-Plane Ligand Functionalization on Semiconducting $2 \mathrm{H}-\mathrm{MoS}_{2}$ Monolayers. ACS Appl. Mater. Interfaces 9 (2017) 12734-12742.

[48] A.C. A. C. Ferrari, J. J. Robertson, Interpretation of Raman spectra of disordered and amorphous carbon. Phys. Rev. B 61 (2000) 14095.

[49] M.A. Pimenta, E. del Corro, B.R. Carvalho, C. Fantini, L.M. Malard, Comparative study of Raman spectroscopy in graphene and $\mathrm{MoS}_{2}$-type transition metal dichalcogenides. Acc. Chem. Res. 48 (2015) 41-47.

[50] G. Eda, H. Yamaguchi, D. Voiry, T. Fujita, M. Chen, M. Chhowalla, Photoluminescence from Chemically Exfoliated $\mathrm{MoS}_{2}$. Nano Lett. 11 (2011) 51115116.

[51] G. Ruan, S.-S. Feng, Preparation and characterization of poly(lactic acid)poly(ethylene glycol)-poly(lactic acid) (PLA-PEG-PLA) microspheres for controlled release of paclitaxel. Biomaters 24 (2003) 5037-5044.

[52] M.A. Lapierre, M. O'Keefe, B.J. Taft, S.O. Kelley, Electrocatalytic Detection of Pathogenic DNA Sequences and Antibiotic Resistance Markers. Anal. Chem. 75 (2003) 6327-6333.

[53] B.E.F. de Avila, H.M. Watkins, J.M. Pingarron, K.W. Plaxco, G. Palleschi, F. Ricci, Determination of the deteciton limit and specificity of surface-based biosensors. Anal. Chem. 85 (2013) 6593-6597.

[54] L.D. Tran, D.T. Nguyen, B.H. Nguyen, Q.P. Do, H.L. Nguyen, Development of interdigitated arrays coated with functional polyaniline/MWCNT for electrochemical biodetection: application for human papilloma virus. Talanta 85 (2011) 1560-1565. 
[55] B. Piro, A. Kapella, V.H. Le, G. Anquetin, Q.D. Zhang, S. Resiberg, V. Noel, L.D. Tran, H.T. Duc, M.C. Pham, Towards the detection of human papillomavirus infection by a reagentless electrochemical peptide biosensor. Electrochim. Acta 56 (2011) 10688-10693.

[56] M. Bartosik, H. Durikova, B. Vojtesek, M. Anton, E. Jandakova, R. Hrstka, Electrochemical chip-based genomagnetic assay for detection of high-risk human papillomavirus DNA. Biosens. Bioelectron. 83 (2016) 300-305.

[57] A. Kowalczyk, A.M. Nowicka, Application of mercury-mediated thymine-base pairs for successful voltammetric detection of HPV 18. Sens. Actuators B 237 (2016) 810-816.

[58] H. Huang, W. Bai, C. Dong, R. Guo, Z. Liu, An ultrasensitive electrochemical DNA biosensor based on graphene/Aunanorod/polythionine for human papillomavirus DNA detection. Biosens. Bioelectron. 68 (2015) 442-446. 